\title{
Mitochondrial Genetic Diversity and Population Structure of the Amur Sleeper (Perccottus glenii) in Northeast China
}

\author{
Peimin Yang*, Zongyun Hu, Yixin Liu, Guanghai Jin and Lei Wang \\ Liaoning Key Laboratory for Prevention and Treatment of Aquatic Animal Diseases, \\ Freshwater Fisheries Research Academy of Liaoning Province, Liaoyang111000, China.
}

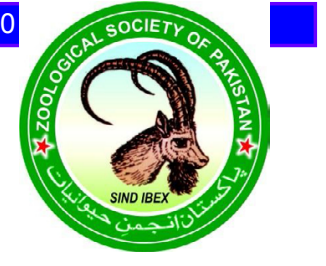

\begin{abstract}
A B S T R A C T
Amur sleeper (Perccottus glenii), is a remarkable invasive species in Euroasia, is natively distributed in Northeast Asia and has been recognized as a candidate for aquaculture in northeast China. To investigate the genetic variability and population structure of this species in its native range, we analysed variation in the mitochondrial cytochrome $\mathrm{b}$ (Cyt $b$ ) for 94 specimens collected from five locations. Sequence analysis showed that there were 50 polymorphic sites and 20 haplotypes among five populations, and the samples exhibited high haplotype diversity $(h=0.8467)$ and low nucleotide diversity $\left(P_{\mathrm{i}}=0.0063\right)$. Genetic distances ranged from 0.0002 to 0.0149 within and 0.0007 to 0.0140 between populations. AMOVA analysis indicated significant genetic differentiation among populations $\left(F_{\mathrm{st}}=0.3202, P<0.01\right)$ and $68.98 \%$ of the total variation was resulted from intra-population differentiation. Pairwise $F_{\text {st }}$ statistics also confirmed the presence of significant differentiation between populations, although no significant differentiation between Panjin and Tieling populations was detected $(P>0.05)$. Moreover, 20 haplotypes identified from the five populations did not cluster into separate geographic branches based on the results of phylogenetic analyses. The neutrality and mismatch distribution tests suggested the species as a whole and all but Tieling population did not undergo a recent population expansion. The results obtained here suggested that Fuyuan, Baoqing and Neimeng populations should be protected and managed separately, and Panjin and Tieling populations should be considered as a genetic management unit.
\end{abstract}

\begin{tabular}{l} 
Article Information \\
Received 17 March 2019 \\
Revised 22 June 2019 \\
Accepted 03 October 2019 \\
Available online 17 April 2020 \\
Authors' Contribution \\
PY conceived and designed the study. \\
ZH and YL performed experimental \\
work and laboratory analysis. PY, GJ \\
and LW wrote the article. \\
Key words \\
\hline Amur sleeper, Perccottus glenii, \\
Genetic diversity, Population \\
structure, Cyt $b$
\end{tabular}

\section{INTRODUCTION}

$\mathrm{T}$ he Amur sleeper (Perccottus glenii), a small benthic freshwater fish, is natively distributed in Russian Far East, northeastern China and northern North Korea (Froese and Pauly, 2018). This species prefers to live in marsh wetlands and shallow lentic habitats of lakes and rivers with dense growth of aquatic plants, avoiding river reaches with fast or even slow currents (Koščo et al., 2003). Since the first introduction into Europe in 1912 (Reshetnikov, 2004), the fish has continuously expanded its geographical distribution and has been one of the most successful European invasive species in recent decades (Reshetnikov and Ficetola, 2011). However, this species didn't expand its range in China. In other word, it couldn't be found outside its native range, which may be attributed to the fact that $P$. glenii has high commercial value and is caught for consumption. Given its economic importance, some attempts have been undertaken to establish entire aquaculture process for this species recently

\footnotetext{
* Corresponding author: pmyang313@163.com 0030-9923/2020/0004-1531\$9.00/0

Copyright 2020 Zoological Society of Pakistan
}

(Jin et al., 2010; Li et al., 2014; Zhang et al., 2017). Even now, exploiting wild populations is still the main way to meet market demand for $P$. glenii due to some bottlenecks for seed production and pond culture.

Knowledge of the genetic diversity of a certain species and how it is distributed within and between populations is essential to provide the parameters necessary for understanding evolutionary aspects, and for developing future management and conservation actions (Frankham et al., 2010; Allendorf et al., 2012). Using all kinds of markers from mitochondrial or nuclear genomes, we have obtained a lot of knowledge on this aspect (Ruzzante et al., 1996; Aboim et al., 2005; Guo et al., 2016). Unfortunately, genetic information on $P$. gelnii is still limited compared to other fish species. In fact, most of studies containing genetic information on this species focused on the invasive populations in Europe (Golubtso et al., 1993; Luca et al., 2014; Zhigileva and Kulikova, 2016). Only one study was devoted to exploring the evolutionary history of $P$. glenii across its native distributional areas (Xu et al., 2014).

Here we used mitochondrial cytochrome $b$ (Cyt $b$ ) gene to investigate the genetic diversity and population structure of $P$. glenii specimens from five sites in northeastern China. Our aims were (1) to enrich the 
existing genetic information on $P$. glenii and (2) provide guidelines for creating management and conservation programs in its native habitats.

\section{MATERIALS AND METHODS}

\section{Sampling and DNA extraction}

Ninety four individuals of wild $P$. glenii from five local populations were collected using fishing cage during 2011 and 2012. Detail information on sampling location is illustrated in Figure 1 and Table I. After capture, pectoral or caudal fin was dissected from each fresh fish, immediately preserved in $95 \%$ alcohol and stored at $4{ }^{\circ} \mathrm{C}$ until DNA isolation. Total DNA was extracted from ethanol-preserved fin following the protocol of Tianamp Genomic DNA Kit (Tiangen Biotch Co., Ltd, China) with minor modifications.

\section{PCR amplification and DNA sequencing}

The fragment of Cyt $b$ gene was amplified using two specific primers: PCytbF (5'-AACCAGGACTAATGGCTTGA-3') and PCytbR (5'-TTTCTAATCAACCCGCTA-3'), which were designed using Primer Premier 5.0 software based on a sequence (NC_020350.1). Polymerase chain reaction (PCR) was completed in $25 \mu \mathrm{L}$ reaction mixture containing $2.5 \mu \mathrm{L} 10 \times \mathrm{PCR}$ buffer $\left(\mathrm{Mg}^{2+}\right.$ plus, $\left.20 \mathrm{mM}\right)$, $2 \mu \mathrm{L}$ dNTP mix $(2.5 \mathrm{mM}), 0.25 \mu \mathrm{L}$ Taq DNA polymerase $(5 \mathrm{U} / \mu \mathrm{L}), 1 \mu \mathrm{L}$ each primer $(10 \mathrm{mM}), 17.25 \mu \mathrm{L}$ ultrapure water and approximately $100 \mathrm{ng}$ of DNA template. The PCR profile consisted of an initial denaturation at $94{ }^{\circ} \mathrm{C}$ for $5 \mathrm{~min}$, followed by 35 cycles of denaturation $\left(94{ }^{\circ} \mathrm{C}\right.$ for $1 \mathrm{~min})$, annealing $\left(55^{\circ} \mathrm{C}\right.$ for $\left.45 \mathrm{~s}\right)$, extension $\left(72^{\circ} \mathrm{C}\right.$ for $1 \mathrm{~min})$, followed by a final extension step of $72^{\circ} \mathrm{C}$ for $7 \mathrm{~min}$. PCR products were purified in $1.5 \%$ agarose and directly sequenced using the PCR primers on Applied Biosystems ABI 3730 DNA Sequencer.

\section{Data analysis}

All sequences were assembled using SeqMan program (DNAStar software package), and aligned using CLUSTALW in MEGA 6.0 (Tamura et al., 2013) after manually examining. Nucleotide composition, numbers of haplotypes $(\mathrm{N})$, haplotype diversity $(h)$, nucleotide diversity $\left(P_{\mathrm{i}}\right)$ and number of polymorphic sites $(\mathrm{n})$ were calculated in DanSP 5.10 (Librado and Rozas, 2009), which was also used to implement the mismath analysis. The Neighbor-Joining (MJ) evolution tree and the Median-Joining (MJ) network were constructed using MEGA 6.0 and Network 4.6.1.6 software (Bandelt et al., 1999), respectively. Differences between populations were assessed with pairwise genetic differentiation values $\left(F_{\text {st }}\right)$ and hierarchical analysis of molecular variance (AMOVA) in Arlequin 3.5 (Excoffier and Lischer, 2010). Tajima' $D$ test (Tajima, 1989) and $\mathrm{F}_{\mathrm{u}}{ }^{\prime} F_{\mathrm{s}}$ test $(\mathrm{Fu}, 1997)$ were used to test whether the neutrality held. The goodness-of-fit of the observed and expected mismatch distributions were tested by calculating the sum of squared deviation (SSD) and raggedness index (r). Both neutral tests and the goodnessof-fit test were performed in Arlequin 3.5.

\section{RESULTS}

\section{Necleotide composition and sequence variation}

After alignment, $1010 \mathrm{bp}$ fragment of mt DNA Cyt $b$ for 94 specimens was used for analysis. 50 polymorphic sites, containing 42 parsimony informative sites and 8 singleton variable sites, were detected from the studied specimens, which accounted for $4.95 \%$ of the total nucleotides. Baoqing population had highest number of polymorphic sites, followed by Neimeng and Tieling population had the least number. The average nucleotide composition for all sequences was as follows: $\mathrm{A}=27.1 \%$, $\mathrm{T}=33.3 \%, \mathrm{C}=24.4 \%$, and $\mathrm{G}=15.3 \%$; with $\mathrm{A} / \mathrm{T}$ contents (60.4\%) higher than $\mathrm{C} / \mathrm{G}(39.7 \%)$. The haplotype diversity (h) and nucleotide diversity $\left(P_{\mathrm{i}}\right)$ among populations ranged from 0.2279 to 0.9415 and from 0.0002 to 0.0146 , respectively. The highest $h$ and $P_{\mathrm{i}}$ were found in Fuyuan, while the lowest were found in Tieling. The overall haplotype diversity and nucleotide diversity were 0.8467 and 0.0063 , respectively (Table I).

\section{Haplotype distribution and population genetic structure \\ 50 polymorphic sites defined a total of 20 haplotypes} (Genebank Accession MG882513-MG882532). Among these 20 haplotypes, 15 haplotypes were unique and 5 haplotypes were shared, while no common haplotype was shared across all populations (Table II). The number of haplotypes in each population ranged from 3 in Tieling to 10 in Fuyuan (Table I). As the most widespread haplotype, Hap1 was dominant in Tieling and Panjin and accounted for $36.17 \%$ of all specimens studied. In contrast, the haplotype Hap16 was only restricted to Fuyuan with a lowest frequency $(1.06 \%)$, as was the haplotype Hap 17 .

As shown in Table III, the genetic distances within populations ranged from 0.0002 in Tieling to 0.0149 in Fuyuan, and the genetic distances between populations ranged from 0.0007 to 0.0140 . Obviously, the genetic distances between Fuyuan and other populations (0.01240.0149 ) were higher than that among four populations, which was also confirmed by the higher Pair-wise $F_{\text {st }}$ values between Fuyuan and other populations. Pairwise $F_{\text {st }}$ values for all population pairs, ranging from 0.0188 to 0.3822 , were significant $(P<0.01)$ with the exception 
Table I. Sampling details and genetic diversity for each population.

\begin{tabular}{llllllll}
\hline Locality & River basin & Geographic coordinates & Sample size & $\mathbf{n}$ & $\mathbf{N}$ & $\mathbf{h}$ & $\mathbf{P}_{\mathbf{i}}$ \\
\hline Fuyuan & Amur river & $48.35^{\circ} \mathrm{N}, 134.68^{\circ} \mathrm{E}$ & 19 & 5 & 10 & 0.9415 & 0.0146 \\
Baoqing & Amur river & $46.21^{\circ} \mathrm{N}, 132.37^{\circ} \mathrm{E}$ & 17 & 33 & 5 & 0.5735 & 0.0050 \\
Neimeng & Ulagai river & $45.53^{\circ} \mathrm{N}, 118.05^{\circ} \mathrm{E}$ & 21 & 7 & 6 & 0.8571 & 0.0020 \\
Tieling & Liaohe river & $42.16^{\circ} \mathrm{N}, 123.74^{\circ} \mathrm{E}$ & 17 & 2 & 3 & 0.2279 & 0.0002 \\
Panjin & Liaohe river & $41.04^{\circ} \mathrm{N}, 122.18^{\circ} \mathrm{E}$ & 20 & 5 & 4 & 0.6105 & 0.0011 \\
Total & & & 94 & 50 & 20 & 0.8467 & 0.0063 \\
\hline
\end{tabular}

n, number of polymorphic sites; N, number of haplotypes; $h$, haplotype diversity; $P_{\mathrm{i}}$, nucleotide diversity.

Table II. Haplotype distributions, haplotype numbers and frequencies in five $P$. glenii populations.

\begin{tabular}{lllllll}
\hline Haplotype & Fuyuan & Baoqing & Neimeng & Tieling & Panjin & Total \\
\hline Hap1 & $0(0)$ & $3(0.1765)$ & $4(0.1905)$ & $15(0.8824)$ & $12(0.6000)$ & $34(0.3617)$ \\
Hap2 & $0(0)$ & $0(0)$ & $0(0)$ & $1(0.0588)$ & $2(0.1000)$ & $3(0.0319)$ \\
Hap3 & $0(0)$ & $0(0)$ & $0(0)$ & $1(0.0588)$ & $4(0.2000)$ & $5(0.0532)$ \\
Hap4 & $0(0)$ & $0(0)$ & $0(0)$ & $0(0)$ & $2(0.1000)$ & $2(0.0213)$ \\
Hap5 & $0(0)$ & $0(0)$ & $4(0.1905)$ & $0(0)$ & $0(0)$ & $4(0.0426)$ \\
Hap6 & $0(0)$ & $0(0)$ & $4(0.1905)$ & $0(0)$ & $0(0)$ & $4(0.0426)$ \\
Hap7 & $0(0)$ & $0(0)$ & $2(0.0952)$ & $0(0)$ & $0(0)$ & $2(0.0213)$ \\
Hap8 & $0(0)$ & $0(0)$ & $5(0.2381)$ & $0(0)$ & $0(0)$ & $5(0.0532)$ \\
Hap9 & $0(0)$ & $0(0)$ & $2(0.0952)$ & $0(0)$ & $0(0)$ & $2(0.0213)$ \\
Hap10 & $0(0)$ & $11(0.6471)$ & $0(0)$ & $0(0)$ & $0(0)$ & $11(0.1170)$ \\
Hap11 & $2(0.1053)$ & $1(0.0588)$ & $0(0)$ & $0(0)$ & $0(0)$ & $3(0.0319)$ \\
Hap12 & $2(0.1053)$ & $1(0.0588)$ & $0(0)$ & $0(0)$ & $0(0)$ & $3(0.0319)$ \\
Hap13 & $2(0.1053)$ & $1(0.0588)$ & $0(0)$ & $0(0)$ & $0(0)$ & $3(0.0319)$ \\
Hap14 & $3(0.1579)$ & $0(0)$ & $0(0)$ & $0(0)$ & $0(0)$ & $3(0.0319)$ \\
Hap15 & $2(0.1053)$ & $0(0)$ & $0(0)$ & $0(0)$ & $0(0)$ & $2(0.0213)$ \\
Hap16 & $1(0.0526)$ & $0(0)$ & $0(0)$ & $0(0)$ & $0(0)$ & $1(0.0106)$ \\
Hap17 & $1(0.0526)$ & $0(0)$ & $0(0)$ & $0(0)$ & $0(0)$ & $1(0.0106)$ \\
Hap18 & $2(0.1053)$ & $0(0)$ & $0(0)$ & $0(0)$ & $0(0)$ & $2(0.0213)$ \\
Hap19 & $2(0.1053)$ & $0(0)$ & $0(0)$ & $0(0)$ & $0(0)$ & $2(0.0213)$ \\
Hap20 & $2(0.1053)$ & $0(0)$ & $0(0)$ & $0(0)$ & $0(0)$ & $2(0.0213)$ \\
\hline
\end{tabular}

of between Panjin and Tieling, suggesting that most of populations studied were significantly different from each other. Furthermore, AMOVA analysis showed significant differentiation among populations with an overall $F_{\text {st }}$ value of $0.3202(\mathrm{P}=0.000)$. The majority of molecular variation was attributed to variation within populations $(67.98 \%)$, which was higher than among populations within basins (29.69\%) and among basins (2.33\%) (Table IV).

\section{Phylogenetic analysis}

A neighbour-joinging(NJ) tree and a net medianjoining(MJ) network were constructed using 20 haplotyes based on Cyt $b$ sequences (Fig. 2). The NJ tree revealed that all haplotypes could be divided into four haplogroups: Clade A, Clade B, Clade C and Clede D. Of these, Clade A contained hayplotypes from all populations except for Fuyuan, while Clade B and Clade D contained hyplotypes mainly derived from Fuyuan. The MJ network also showed all 20 haplotypes were grouped in four branches, which corresponded to Clade A, Clade B, Clade C and Clade D. Furthermore, the haploytpe Hapl was likely to be ancestral to other haplotypes, given its abundance and centrality in CladeA. 
Table III. Genetic distance between (below diagonal) and within (diagonal) P.glenii populations, and the Pairwise $F_{\text {st }}$ values (upper diagonal) between populations.

\begin{tabular}{llllll}
\hline & Fuyuan & Baoqing & Neimeng & Tieling & Panjin \\
\hline Fuyuan & 0.0149 & $0.2808^{* *}$ & $0.3822^{* *}$ & $0.3764^{* *}$ & $0.3677^{* *}$ \\
Baoqing & 0.0140 & 0.0051 & $0.2378^{* *}$ & $0.2429^{* *}$ & $0.2277^{* *}$ \\
Neimeng & 0.0134 & 0.0045 & 0.0020 & $0.1150^{* *}$ & $0.0961^{* *}$ \\
Tieling & 0.0124 & 0.0035 & 0.0013 & 0.0002 & 0.0188 \\
Panjin & 0.0125 & 0.0039 & 0.0017 & 0.0007 & 0.0011 \\
\hline
\end{tabular}

**significant values $(P<0.01)$.

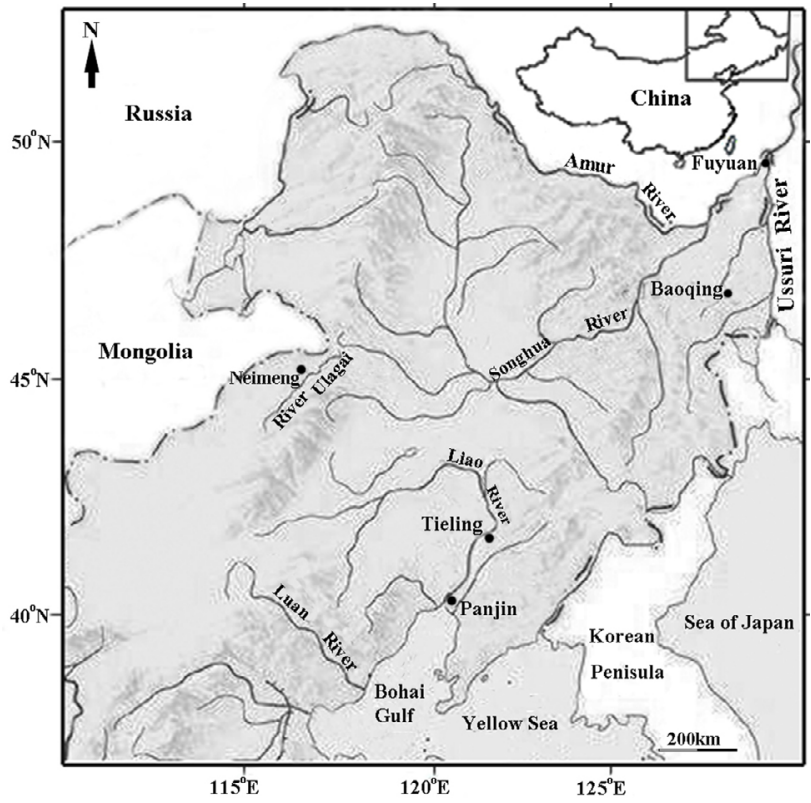

Fig. 1. Map showing the five sampling sites of $P$. glenii in northeast China.

\section{Neutrality tests and demographic history}

Negative Tajima' $D$ values were found in Tieling and Baoqing populations, and only Tieling population significantly deviated from neutrality. $\mathrm{F}_{\mathrm{u}}{ }^{\prime} F_{\mathrm{s}}$ test displayed that both Neimeng and Tieling showed negative $\mathrm{F}_{\mathrm{u}}{ }^{\prime} F_{\mathrm{s}}$ values, whereas the significant negative $\mathrm{F}_{\mathrm{u}}{ }^{\prime} F_{\mathrm{s}}$ value was only found in Tieling (Table V), suggesting Tieling population may have suffered a recent population expansion or bottleneck. However, results from both Tajimas' $D$ and $\mathrm{F}_{\mathrm{u}}{ }^{\prime} F_{\mathrm{s}}$ tests indicated that the species as whole had not experienced population expansion, which was also indicated by the multimodal shape of mismatch distribution (Fig. 3). In goodness-of -fit test, P values for the sum of squared deviations (SSD) and raggedness index (r) values were greater than or equal to 0.05 in all populations except for Baoqing. Given the significant $\mathrm{P}$ value for SSD and the absence of significant $\mathrm{F}_{\mathrm{u}}{ }^{\prime} F_{\mathrm{s}}$ value, Baoqing population was at equilibrium although it showed a significant Tajima' $D$ values. Similarly, Neimeng population did not indicate demographic expansion because of the absence of significant Tajima' $D$ and $\mathrm{F}_{\mathrm{u}}$ ' $F_{\mathrm{s}}$ values, although it showed a clearly unimodal shape of mismatch distribution. Collectively, all populations but Tieling were relatively stable.

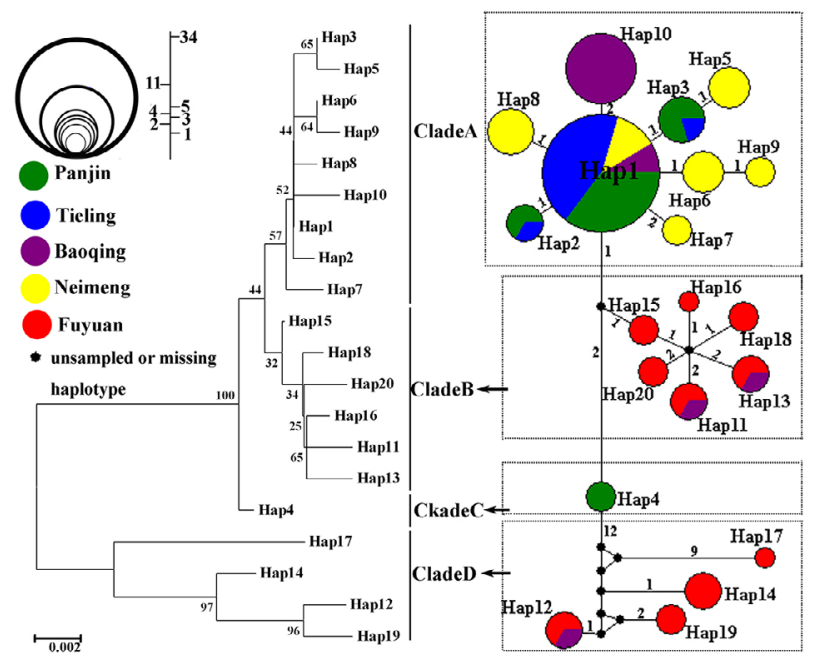

Fig. 2. The NJ tree and MJ network of all 20 haplotypes for five $P$. glenii populations. The size of each circle indicates the number of haplotypes represented. Numbers between haplotypes presented mutational steps.

\section{DISCUSSION}

In our study, the overall population of $P$. glenii had high haplotype diversity and low nucleotide diversity, which was similar in haplotype diversity but slightly lower in nucleotide diversity compared with previous data ( $h=0.852 ; P_{\mathrm{i}}=0.0112$ ) (Xu et al., 2014). The reason for the slight difference may be due to the differences in sampling sites, sample size and sequence region between two studies. In addition, the high haplotype diversity and low nucleotide diversity obtained here was commonly consistent with the other gobioid fishes (Hou et al., 2014; Zheng and Li, 2017). Given the fact that the accumulation of nucleotide diversity spends longer time than haplotype diversity, it is better using nucleotide diversity to reflect genetic diversity than haplotype diversity (Grant and Bowen, 1998). Thus, the genetic diversity of $P$. glenii studied here was relative poor. Meanwhile, this low nucleotide diversity reflected low divergence between haplotypes, as indicated by the short branch lengths on the NJ tree (Fig. 3). Among five $P$. 
Table IV. Analysis of molecular variances based on mtDNA Cyt $b$ sequences.

\begin{tabular}{lllllll}
\hline Source of variation & df & $\begin{array}{l}\text { Sum of } \\
\text { squares }\end{array}$ & $\begin{array}{l}\text { Variance } \\
\text { components }\end{array}$ & $\begin{array}{l}\text { Percentage of } \\
\text { variation }\end{array}$ & $\begin{array}{l}\text { Fixation } \\
\text { indices }\end{array}$ & $\begin{array}{l}\text { significance } \\
\text { tests }\end{array}$ \\
\hline Among groups & 2 & 48.382 & 0.0789 & 2.33 & $\mathrm{~F}_{\mathrm{CT}}=0.0233$ & 0.3226 \\
Among populations within groups & 2 & 41.139 & 1.0058 & 29.39 & $\mathrm{~F}_{\mathrm{SC}}=0.3040$ & 0.0010 \\
Within Populations & 89 & 204.979 & 2.3031 & 68.98 & $\mathrm{~F}_{\mathrm{ST}}=0.3202$ & 0.0000 \\
Total & 93 & 294.50 & 3.3878 & & & \\
\hline
\end{tabular}

Table V. Results from neutrality tests and goodness-of-fit tests for five $P$. glenii populations.

\begin{tabular}{|c|c|c|c|c|c|c|c|c|}
\hline \multirow[t]{2}{*}{ Population } & \multicolumn{2}{|c|}{ Tajima' D } & \multicolumn{2}{|c|}{$\mathbf{F}_{\mathrm{u}}{ }^{\prime} \mathbf{F}_{\mathrm{s}}$} & \multicolumn{4}{|c|}{ Goodness-of-fit test } \\
\hline & D & $\mathbf{P}$ & $\mathbf{F}_{\mathrm{s}}$ & $\mathbf{P}$ & SSD & $\mathbf{P}$ & $\mathbf{r}$ & $\mathbf{P}$ \\
\hline Fuyuan & 1.0318 & 0.8610 & 2.6941 & 0.9060 & 0.0604 & 0.1200 & 0.0731 & 0.0500 \\
\hline Baoqing & -1.9915 & 0.0050 & 3.4060 & 0.9330 & 0.4232 & 0.0000 & 0.3674 & 0.9500 \\
\hline Neimeng & 0.0905 & 0.5970 & -0.1836 & 0.4830 & 0.0125 & 0.2500 & 0.0621 & 0.4300 \\
\hline Tieling & -1.5036 & 0.0430 & -1.6803 & 0.0210 & 0.0029 & 0.5200 & 0.3496 & 0.6100 \\
\hline Panjin & -0.6831 & 0.2880 & 0.2023 & 0.5400 & 0.0239 & 0.2200 & 0.1286 & 0.4000 \\
\hline Total & -0.6112 & 0.3604 & 0.8877 & 0.5796 & 0.1046 & 0.1794 & 0.1962 & 0.4880 \\
\hline
\end{tabular}
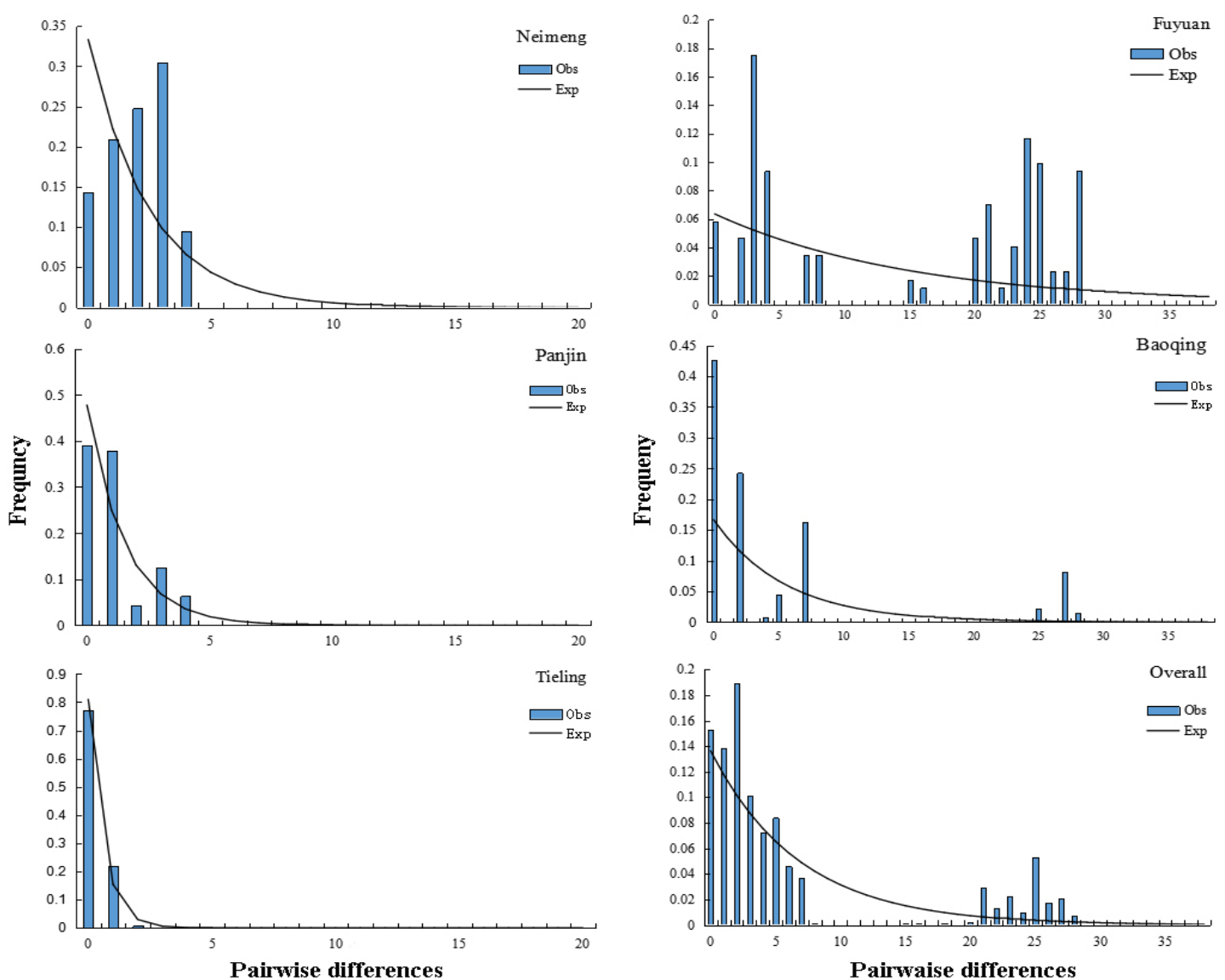

Fig. 3. Observed (bar) and expected (line) mismatch distribution for P. glenii populations. 
glenii populations, Tieling and Fuyuan showed the lowest and highest genetic diversity, respectively. This result might be related to their ecological environments. In fact, Fuyuan population was located adjacent to the boundary between China and Russia and human disturbance was little, which might contribute to the preservation of genetic diversity. Conversely, Tieling population living near the capital of Liaoning province in northeastern China, was likely to suffer overfishing, water pollution and ecological habitat damage. These factors from human activities can result in the recession of wild resources and genetic diversity of $P$. glenii.

Different from some freshwater fishes whose population structures are mainly dependent on the distribution of the river systems (Yakoyama and Coto, 2002; Nagarajan et al., 2006; Zhou et al., 2015), we did not find significant relationship between population genetic similarity and river system, as indicated by genetic distances between populations. For example, the genetic distance between Baoqing and Fuyuan was higher than that between Baoqing and the remaining three populations, although both Baoqing and Fuyuan populations belong to Amur River system. Additionally, Tieling and Neimeng populations, which are geographically distant from each other and belong to different river systems, showed a nearer relationship. Similar reports were found in some fishes such as Gymncypris eckloni (Qi, 2009), Procypris rabaudi (Song et al., 2014) and Scomberomorus commerson (Cao et al., 2016). In fact, the NJ tree and MJ network showed no distinct geographic structure in haplotype distribution, which also confirmed the findings described above. Nonetheless, AMOVA analysis and Pairwise $F_{\text {st }}$ statistics indicated that there was significant genetic structure among populations. Indeed, the overall $F_{\text {st }}$ values was significant, suggesting there was a higher level of genetic differentiation among populations. Furthermore, almost all of population pairs exhibited significant $F_{\text {st }}$ values, confirming the presence of genetic divergence among populations. Generally, climatic changes act an important role in driving the formation of genetic divergence for freshwater fishes (Gante et al., 2009; Gao et al., 2012; Kawamura et al., 2009; Seifertová et al., 2012). Northeast Asia experienced repeated Pleistocene climate changes with cold and dry climate during glacial periods and warm and humid climate during interglacial periods (Stebich et al., 2009; Tarasov et al., 2011), which resulted in the fragmentation of aquatic habits in this region. So, this genetic differentiation found in $P$. glenii could be related to an ancient allopatric fragmentation caused by Pleistocene climate oscillations (Xu et al., 2014). In addition to historical reason, some behavior traits such as sedentary habit, demersal habit, slow action and limited swimming ability also promoted the formation of high level of genetic structure in $P$. gelnii, as found in other gobioid fishes such as Mogurnda adspersa (Hughes et al., 2012) and Odontobutis potamophila (Hou et al., 2014).

In order to examine the population history of five $P$. glenii populations, the neutrality tests, goodness-offit test and mismatch analysis were carried out in this study. Significantly negative Tajima' $D$ value and $\mathrm{F}_{\mathrm{u}}{ }^{\prime} F_{s}$ value were only found in Tieling population, indicating that Tieling experienced a recent population expansion. Similarly, the unimodal shape of the mismatch distribution plot and non-significant SSD and $r$ values also suggested a population expansion event happened in Tieling population. Considering the low genetic diversity Tieling population showed, this population might expand rapidly from a small population. In terms of the remaining four populations, the absence of significant Tajima' $D$ and $\mathrm{F}_{\mathrm{u}}$ ' $F_{s}$ values, and multimodal mismatch distributions rejected the hypothesis that these populations passed through a bottleneck and population expansion.

Presently, freshwater fishes are recognized as among the most threatened; as such, their conservation is of the utmost importance (Vila et al., 2013). For effective conservation and management of wild fish populations, assigning evolutionary significant units (ESUs) and management units (MUs) was widely used (He et al., 2012; Song et al., 2014; Jean et al., 2014; Zhu et al., 2016). Our study revealed that the genetic differentiation between Tieling and Panjin populations were not significant; therefore, we suggested the two populations could be considered as a single genetic management unit. The genetic divergences among Fuyuan, Neimeng and Baoqing populations were significant; thus Fuyuan, Neimeng and Baoqing populations should be protected and managed separately. Importantly, Fuyuan and Neimeng populations contained some unique haplotypes, which may be considered important for aquaculture (Thai et al., 2006) and provide the necessary spectrum of genotype for adaptive response to changing environment (Thai et al., 2007). These unique haplotypes, as well as rare haplotypes (e.g. Hap16 and Hap17 in Fuyuan population) in wild may be lost easily, which may prevent future improvement of the species via selection and could reduce viability in populations that were stocked in lakes and rivers (Zhou et al., 2015). So, Fuyuan and Neimeng populations should need special conservation. In addition, anthropogenic disturbance, namely overfishing, environmental pollution and introduction of alien species, may have elicited significant pressures on the genetic diversity of freshwater fishes (Agostinho et al., 2005; Hou et al., 2014; Guo et al., 2016). To protect this species, some measures such as limiting fishing, strengthening management of invasive 
alien species, establishment of reserve areas for spawners and improving habit quality should be taken. Meanwhile, artificial breeding and cultivation of $P$. glenii should also be enhanced to alleviate the reduction of wild resources and meet market demand.

Due to the known shortcomings of mtDNA marker (Ballard and Whitlock, 2004) and the limited number of individuals analyzed in this study, future works comprising a higher number of individuals and populations, should employ multiple nuclear and mitochondrial markers (Guo et al., 2018) to get even more information about the population genetic structure and phylogeography of this species.

\section{CONCLUSIONS}

The Cyt $b$ gene sequences revealed high haplotype diversity and low nucleotide diversity among five $P$. glenii populations. Genetic structuring among sampling populations was significant. The analysis of genetic diversity and population structure suggested that Fuyuan, Baoqing and Neimeng populations should be protected and managed separately, and Panjin and Tieling populations should be considered as a genetic management unit.

\section{Statement of conflict of interest}

Authors have declared no conflict of interest.

\section{ACKNOWLEDGMENT}

This study was supported by three funds from Department of Science and Technology of Liaoning Province (project no. 2013002016, 2014002015 and 20180020).

\section{REFERENCES}

Aboim, M.A., Menezes, G.M., Schlitt, T. and Rogers, A.D., 2005. Genetic structure and history of populations of the deep-sea fish Helicolenus dactylopterus (Delaroche, 1809) inferred from mtDNA sequence analysis. Mol. Ecol., 14: 1343-1354. https://doi.org/10.1111/j.1365294X.2005.02518.x

Agostinho, A.A., Thomaz, S.M. and Gomes, L.C., 2005. Conservation of the biodiversity of Brazil's inland waters. Conserv. Biol., 19: 646-652. https:// doi.org/10.1111/j.1523-1739.2005.00701.x

Allendorf, F.W., Luikart, G.H. and Aitken S.N., 2012. Conservation and the genetics of populations. $2^{\text {nd }}$ edn. Wiley Blackwell Publishing, Oxford.

Ballard, J.W.O. and Whitlock, M.C., 2004. The incomplete natural history of mitochondria. Mol. Ecol., 13: 729-744. https://doi.org/10.1046/j.1365294X.2003.02063.x

Bandelt, H.J., Forster, P. and Röhl, A., 1999. Medianjoining networks for inferring intraspecific phylogenies. Mol. biol. Evol., 16: 37-48. https:// doi.org/10.1093/oxfordjournals.molbev.a026036

Cao, Y., Zhang, Q., Gong, Y.Y., Lü, J.L. and Yang, X.S., 2016. Genetic variation of mtDNA COI sequence of Scomberomorus commerson populations in the South China Sea. S. China Fish. Sci., 12: 53-60.

Excoffier, L. and Lischer, H.E., 2010. Arlequin suite ver 3.5: a new series of programs to perform population genetics analyses under Linux and Windows. Mol. Ecol. Resour., 10: 564-567. https://doi.org/10.1111/ j.1755-0998.2010.02847.x

Frankham, R., Ballou, J.D. and Briscoe, D.A., 2010. Introduction to conservation genetics. $2^{\text {nd }}$ edn. Cambridge University Press, Cambridge. https:// doi.org/10.1017/CBO9780511809002

Froese, R. and Pauly, D., 2018. Fish Base. [Version 02/2018]. www.fishbase.org

Fu, Y.X., 1997. Statistical tests of neutrality of mutations against population growth, hitchhiking and background selection. Genetics, 147: 915-925.

Gante, H.F., Micael, J., Oliva-Paterna, F.J., Doadrio, I., Dowling, T.E. and Alves, M.J., 2009. Diversification within glacial refugia: tempo and mode of evolution of the polytypic fish Barbus sclateri. Mol. Ecol., 18: 3240-3255. https://doi. org/10.1111/j.1365-294X.2009.04264.x

Gao, Y., Wang, S.Y., Luo, J., Murphy, R.W., Du, R., Wu, S.F. and Luan P.T., 2012. Quaternary palaeoenvironmental oscillations drove the evolution of the Eurasian Carassius auratus complex (Cypriniformes, Cyprinidae). J. Biogeogr., 39: 2264-2278. https://doi.org/10.1111/j.13652699.2012.02755.x

Golubtsov, B.A., Ilyin, I.I. and Mina, M.V., 1993. Polymorphisms at two enzyme loci (Sod and Odh) in populations of the Amur sleeper, Perccottus glenii (Pisces, Eleotrididae), from its native range and the colonized area: the effect of introduction on genetic variation. J. Zool. Syst. Evol. Res., 31: 269279. https://doi.org/10.1111/j.1439-0469.1993. tb00196.x

Grant, W.A.S. and Bowen, B.W., 1998. Shallow population histories in deep evolutionary lineages of marine fishes: insights from sardines and anchovies and lessons for conservation. J. Hered., 89: 415426. https://doi.org/10.1093/jhered/89.5.415

Guo, X.Z., Zhang, G.R., Wei, K.J., Yan, R.J., Ji, W., 
Yang, R.B. and Gardner, J.P., 2016. Phylogeography and population genetics of Schizothorax o'connori: strong subdivision in the Yarlung Tsangpo River inferred from mtDNA and microsatellite markers. Sci. Rep., 6: 29821. https://doi.org/10.1038/ srep29821

Guo, B., Chen, Y., Zhang, C., Lv, Z., Xu, K., Ping, H. and Shi, H., 2018. Characterization of complete mitochondrial genome and phylogeny of Sepia lycidas (Sepioidea, Sepiidae). Pakistan J. Zool., 50: 1497-1508. http://dx.doi.org/10.17582/journal. pjz/2018.50.4.1497.1508

He, Y., Wang, J., Blanchet, S. and Lek, S., 2012. Genetic structure of an endangered endemic fish (Gobiocypris rarus) in the upper Yangtze River. Biochem. Syst. Ecol., 43: 214-225. https://doi. org/10.1016/j.bse.2012.03.010

Hou, X., Zhu, F., Yin, S., Zhang, L., Hu, Y., Wang, Y. and Li, L., 2014. Genetic diversity of Odontobutis potamophila from different geographic populations inferred from mtDNA control region. Mitochond. DNA, 25: 400-406. https://doi.org/10.3109/194017 36.2013.803084

Hughes, J.M., Real, K.M., Marshall, J.C. and Schmidt, D.J., 2012. Extreme genetic structure in a small-bodied freshwater fish, the purple spotted gudgeon, Mogurnda adspersa (Eleotridae). PLoS One, 7: e40546. https://doi.org/10.1371/journal. pone. 0040546

Jean, C.T., Wu, C.Y., Tsai, K.C., Wang, W.K., Hsu, Y.Y., Chang, Y.M. and Lin, H.D., 2014. Population genetic structure in the endemic cyprinid fish Microphysogobio alticorpus in Taiwan: evidence for a new phylogeographical area. Biochem. Syst. Ecol., 57: 108-116. https://doi.org/10.1016/j. bse.2014.07.019

Jin, G.H., Liu, Y.X. and Yang, P.M., 2010.Prelinimary study on artificial reproduction of Amur sleeper, Perccottus glenii. Mod. Agric. Sci. Technol., 15: pp. 235.

Kawamura, K., Yonekura, R., Katano, O., Taniguchi, Y. and Saitoh, K., 2009. Phylogeography of the bluegill sunfish, Lepomis macrochirus, in the Mississippi river basin. Zool. Sci., 26: 24-34. https://doi. org/10.2108/zsj.26.24

Koščo, J., Lusk, S., Halacka, K. and Luskova, V., 2003. The expansion and occurrence of the Amur sleeper (Perccottus glenii) in eastern Slovakia. Folia Zool., 52: 329-336.

Li, Z.Q., Yang, J., Li, Q., Zheng, D., Wang, Y.B. and Huang, P.H. 2014. Effects of Temperature on Ingestion and growth of Perccottus glenii. J. Anhui
Agric. Sci., 42: 4662-4663.

Librado, P. and Rozas, J., 2009. DnaSP v5: a software for comprehensive analysis of DNA polymorphism data. Bioinformatics, 25: 1451-1452. https://doi. org/10.1093/bioinformatics/btp187

Luca, M., Ureche, D., Nicuta, D., Ghiorghita, G., Druica, R.C. and Gorgan, L.D., 2014. The genetic variability of the invasive Perccottus glenii from Siret River, using the cytochrome b gene. Annls Roman. Soc. Cell Biol., 19: 11-20.

Nagarajan, M., Haniffa, M.A., Gopalakrishnan, A., Basheer, V.S. and Muneer, A., 2006. Genetic variability of Channa punctatus populations using randomly amplified polymorphic DNA. Aquacul. Res., 37: 1151-1155. https://doi.org/10.1111/j.13652109.2006.01539.x

Qi, D.L., 2009. Genetic Variation and diversity of Gymncypris eckloni in the Upper Yellow River inferred from mitochondrial cytochrome $b$ gene. Zool. Res., 30: 255-261.

Reshetnikov, A.N., 2004. The fish Perccottus glenii: history of introduction to western regions of Eurasia. Hydrobiologia, 522: 349-350. https://doi. org/10.1023/B:HYDR.0000030060.29433.34

Reshetnikov, A.N. and Ficetola, G.F., 2011. Potential range of the invasive fish rotan (Perccottus glenii) in the Holarctic. Biol. Invasions, 13: 2967-2980. https://doi.org/10.1007/s10530-011-9982-1

Ruzzante, D.E., Taggart, C.T., Cook, D. and Goddard, S., 1996. Genetic differentiation between inshore and offshore Atlantic cod (Gadus morhua) off Newfoundland: microsatellite DNA variation and antifreeze level. Can. J. Fish. aquat. Sci., 53: 634645. https://doi.org/10.1139/cjfas-53-3-634

Seifertová, M., Bryja, J., Vyskočilová, M., Martínková, N. and Šimková, A., 2012. Multiple Pleistocene refugia and post-glacial colonization in the European chub (Squalius cephalus) revealed by combined use of nuclear and mitochondrial markers. J. Biogeogr., 39: $1024-1040 . \quad$ https://doi.org/10.1111/j.13652699.2011.02661.x

Song, J., Hou, F., Zhang, X., Yue, B., Song, Z., 2014. Mitochondrial genetic diversity and population structure of a vulnerable freshwater fish, rock carp (Procypris rabaudi) in upper Yangtze River drainage. Biochem. Syst. Ecol., 55: 1-9. https://doi. org/10.1016/j.bse.2014.02.008

Stebich, M., Mingram, J., Han, J. and Liu, J., 2009. Late Pleistocene spread of (cool-) temperate forests in Northeast China and climate changes synchronous with the North Atlantic region. Global Planet. Change, 65: 56-70. https://doi.org/10.1016/j. 
gloplacha.2008.10.010

Tajima, F., 1989. Statistical method for testing the neutral mutation hypothesis by DNA polymorphism. Genetics, 123: 585-95.

Tamura, K., Stecher, G., Peterson, D., Filipski, A. and Kumar, S., 2013. MEGA6: molecular evolutionary genetics analysis version 6.0. Mol. Biol. Evol., 30: 2725-2729. https://doi.org/10.1093/molbev/mst197

Tarasov, P.E., Nakagawa, T., Demske, D., Österle, H., Igarashi, Y., Kitagawa, J. and Miyoshi, N., 2011. Progress in the reconstruction of quaternary climate dynamics in the Northwest Pacific: a new modern analogue reference dataset and its application to the 430-kyr pollen record from Lake Biwa. EarthSci. Rev., 108: 64-79. https://doi.org/10.1016/j. earscirev.2011.06.002

Thai, B.T., Burridge, C.P. and Austin, C.M., 2007. Genetic diversity of common carp (Cyprinus carpio L.) in Vietnam using four microsatellite loci. Aquaculture, 269: 174-186. https://doi. org/10.1016/j.aquaculture.2007.05.017

Thai, B.T., Pham, T.A. and Austin, C.M., 2006. Genetic diversity of common carp in Vietnam using direct sequencing and SSCP analysis of the mitochondrial DNA control region. Aquaculture, 258: 228-240. https://doi.org/10.1016/j.aquaculture.2006.03.025

Vila, I., Morales, P., Scott, S., Poulin, E., Véliz, D., Harrod, C. and Méndez, M.A., 2013. Phylogenetic and phylogeographic analysis of the genus Orestias (Teleostei: Cyprinodontidae) in the southern Chilean Altiplano: the relevance of ancient and recent divergence processes in speciation. J. Fish Biol., 82: 927-943. https://doi.org/10.1111/jfb.12031

Xu, W., Yin, W., Chen, A., Li, J., Lei, G. and Fu, C., 2014.
Phylogeographical analysis of a cold-temperate freshwater fish, the Amur sleeper (Perccottus glenii) in the Amur and Liaohe River Basins of Northeast Asia. Zool. Sci., 31: 671-679. https://doi. org/10.2108/zs130046

Yokoyama, R. and Goto, A., 2002. Phylogeography of a freshwater sculpin, Cottus nozawae, from the northeastern part of Honshu Island, Japan. Ichthyol. Res., 49: 147-155. https://doi.org/10.1007/ s102280200019

Zhang, Y.Y., Wang, C.A., Jia, Z.Y., Yu, Y.Y., Bai, Q.L., 2017. Analysis of nutritional composition of Perccottus glenii muscle. Acta Nutri. Sin., 39: 515517.

Zheng, X. and Li, C.H., 2017. Population structure and genetic divergence of Micropercops swinhonis. J. Shanghai Ocean Univ., 26: 358-365.

Zhigileva, O.N. and Kulikova, A.A., 2016. Specific biological features and genetic variation of Chinese sleeper Perccottus glenii (Odontobutidae) in aquatic bodies of Tyumen oblast. J. Ichthyol., 56: 124-132. https://doi.org/10.1134/S0032945216010173

Zhou, A., Zhuo, X., Zou, Q., Chen, J. and Zou, J., 2015. Population genetic diversity of the northern snakehead (Channa argus) in China based on the mitochondrial DNA control region and adjacent regions sequences. Mitochond. DNA, 26: 341-349. https://doi.org/10.3109/19401736.2014.908355

Zhu, Y., Cheng, Q. and Rogers, S.M., 2016. Genetic structure of Scomber japonicus (Perciformes: Scombridae) along the coast of China revealed by complete mitochondrial cytochrome $\mathrm{b}$ sequences. Mitochond. DNA Part A, 27: 3828-3836. https://doi. org/10.3109/19401736.2014.958671 